\title{
プラスチック段ボール
}

本州製紙 侏 中央研究所 松 岡 弘, 浅 井良弘

\section{Plastic Corrugated Board}

\section{Hiroshi Matsuoka and Yoshihiro Asai}

Honshu Paper Co., Ltd.

\section{1.はじめに}

我国に初めて段ボールが登場したのは明治の末で, 電球の包装に片段が使われたのが最初と聞いている。 本格的な普及は今から約 15 年前，本州製紙が釧路に 大模規な段ボール原紙製造の工場を建設してからであ 'る。

現在では段ボールは家庭電化品などの工業製品から 野菜果物などの農産物特よび水産加工品に至るまであ らゆる分野に普及している。ただ，一部耐水性を必要 とする水産物関係が未開拓の分野として残されている。

そこで登場したのが完全耐水性であるプラスチック 段ボール（以後簡略のためにプラ段と呼ぶ）である。 プラ段そのものはそんなに新しいものでなく，1961〜 62 年頃から研究開発され，1966 年頃には生産肘売さ れるようになった。その後，各社でいろいろな方式の プラ段が開発され，現在では 10 数社で研究開発また は製造販売が行なわれている。

まだ紙段ボールに比べると価格は高いが，木材資源 の枯渴が深刻な問題となりつつある昨今では，その完 全耐水性, 美粈性の特性とあいまって独自の分野に使 用されつつある。

しかし一面プラスチックの廃裹処理問題が発生し, 処理する場合の発熱量が少なく，有害ガスの発生を規 制する必要にせすられている。これ等に対処するため
プラスチックと無機物との複合材料，特に大量に無機 物を充填したポリオレフィン系複合材料が研究開発さ れ，易燒却性樹脂，無公害樹脂といったキャッチフレ 一ズで市場に登場して注目をあつめている。これら新 しい発想で開発された無機物複合材料を素材とした段 ボールの主なものは，本州ライオンのカルプ段ボール， 三菱油化ーレンゴーのエコロ，日本ゼオンの F R 602 などがある。

\section{2. プラスチック段ボール}

\section{1 製造方式による特徵}

プラ段を製造方法から分類すると，コルゲート方式， 押出し成型方式，組合せ方式の 3 つ分けられる。

(下表参照)。

コルゲート方式は中芯を段繰りしたあと，上下のラ イナーを貼り合せるが，この際接着剂を使用する場合 と熱融着する場合とがある。この方式には一般の紙段 ボールのコルゲーターを一部改良するだけでそのまま 利用する方法もある。また紙段ボールとプラ段を 1 台 のマシンで製造することも可能である。技術的には段 繰りが難かしいことや接着剤が限定されるなど種々問 題があるが，特徵としては生産性が高い方式であり， 製造に融通性がある。

一方押出し成型方式は段ボールの断面形状のダイス を通してワン・ステップで製造できること，設備がコ

\begin{tabular}{|c|c|}
\hline 類 & 造 \\
\hline コルゲート方式 & $\begin{array}{l}\text { プラスチックシートを段ロールで段繰り成型し，2 枚のライナーシ } \\
\text { ートを接着剤などで貼合す方法 }\end{array}$ \\
\hline 押出乙成型方式 & $\begin{array}{l}\text { エクスルーダーで溶融したプラスチックを，段ボール断面形状のダ } \\
\text { イスを通して押出す方法 }\end{array}$ \\
\hline 組 合 方式 & $\begin{array}{l}\text { 中芯の成型方法は段ロールでの段繰り，エクスルーダーの押出し， } \\
\text { 真空成型なぞ種々あるが，ライナーシートとの接着は全て熱融着の } \\
\text { 方法 }\end{array}$ \\
\hline
\end{tabular}


第1表 プラスチック段ボールメーカー

\begin{tabular}{|c|c|c|c|c|c|}
\hline No. & 会 & 商 品 名 & 使用材料 & 造 方 & 備 “考 \\
\hline 1 & $\begin{array}{llll}\text { 日 } & \text { 本 } & \text { 合 } & \text { 成 } \\
\text { 段 } & \text { ボ } & \text { ル }\end{array}$ & $\begin{array}{l}\text { ニチダ ゾ } \\
\text { プラボード }\end{array}$ & ポリスチレン & コルゲート方式，溶剤接着 & $\begin{array}{l}\text { 日曹化工, }, ~ \\
\text { サヒ紙工 }\end{array}$ \\
\hline 2 & 三井石油化学 & C\&L 段ボール & ポリエチレン & $\begin{array}{l}\text { コルゲート方式, 接着はあらかじめ } \\
\text { ライナーに塗布さ机た EVA の在 } \\
\text { による }\end{array}$ & \\
\hline 3 & 三 菱 油 化 & I $=\square$ & $\begin{array}{l}\text { 無機物十ポリエ } \\
\text { チレン }\end{array}$ & $\begin{array}{l}\text { コルゲート方式, ポリプロピレンフ } \\
\text { イルム, サンドイッチ, 熱融着 }\end{array}$ & $\begin{array}{l}\text { レソゴー, 三 } \\
\text { 菱油化 }\end{array}$ \\
\hline 4 & 本州ライオン & カ $ル フ^{\circ}$ & $\begin{array}{l}\text { 無機物十ポリエ } \\
\text { チレシ }\end{array}$ & コルゲートオ式, ホットメルト接着 & $\begin{array}{l}\text { 本州製紙, ラ } \\
\text { イオン油脂 }\end{array}$ \\
\hline 5 & 東 缶 興 業 & ダンプラェース & $\begin{array}{l}\text { ポリエチレン } \\
\text { ポリプロピレン }\end{array}$ & 押出乙成型方式, 一体成型 & \\
\hline 6 & 宇部日東化成 & ダンプレート & ポリプロピレン & 押出乙成型方式, 一体成型 & \\
\hline 7 & 赤ラスチッ菘 & アプトン & ポリエチレン & シート押出し $\rightarrow$ 中芯段繰り $\rightarrow$ 熱融着 & 三菱化成 \\
\hline 8 & 三 井 東 圧 & J P段ボール & ポリプロピレン & 押出し成型 $\rightarrow$ 熱融着 & $\begin{array}{l}\text { 日本紙パルプ } \\
\text { 商事 }\end{array}$ \\
\hline 9 & 日石樹脂化学 & プラパール & ポリエチレン & 中芯真空成型 $\rightarrow$ 熱融着 & $\begin{array}{l}\text { トーモク，日 } \\
\text { 石樹脂化学 }\end{array}$ \\
\hline 10 & 日本サンプライ & サンプライ & ポリプロピレン & 傾斜式射出成型 $\rightarrow$ 熱融着 & $\begin{array}{l}\text { 住友化学, レ } \\
\text { ジー }\end{array}$ \\
\hline 11 & 東 洋 化 学 & タフダン & & 真空成型 $\rightarrow$ 熱融着 & \\
\hline 12 & 日 産 化 学 & ダンシート & ポリエチレン & コルゲート方式 & \\
\hline
\end{tabular}

第2表 各種プラスチック段ボールの物性

\begin{tabular}{|c|c|c|c|c|c|c|c|}
\hline \multicolumn{2}{|c|}{ 製造方式 } & \multicolumn{2}{|c|}{ コルゲート方式 } & \multicolumn{2}{|c|}{ 押出乙成型方式 } & \multirow{2}{*}{$\frac{\text { 組合せ方式 }}{\text { アプトン }}$} & \multirow{2}{*}{$\frac{\text { 紙段ボール }}{-}$} \\
\hline \multirow{3}{*}{\multicolumn{2}{|c|}{ 試験項目 }} & $\begin{array}{l}\text { ニチダン } \\
\text { プラボード }\end{array}$ & $\begin{array}{l}\text { カルプ } \\
\text { 段ボール }\end{array}$ & $\begin{array}{l}\text { ダンプラ } \\
\text { エース }\end{array}$ & J P段ボール & & \\
\hline & & P S & P E + 無機物 & P P & P P & P E & 紙 \\
\hline & & 剂 & ホットメルト & 熱融着 & 熱融着 & 熱融着 & デンプン \\
\hline フルート & - & $\mathrm{B}$ & $\mathrm{C}$ & - & $\mathrm{A}$ & $\mathrm{A}$ & A \\
\hline 米 坪 量 & $\mathrm{g} / \mathrm{m}^{2}$ & 580 & 1,080 & 700 & 1,080 & 800 & 650 \\
\hline 厚夏 さ & $\mathrm{mm}$ & 2.7 & 4.3 & 3.7 & 5.1 & 5.0 & 5.1 \\
\hline 破 裂 強 さ & $\mathrm{kg} / \mathrm{cm}^{2}$ & - & 10.5 & 測定不能 & 湘定不能 & 測定不能 & 16.4 \\
\hline コ ラ ム & & 10.0 & 21.5 & 13.9 & 21.0 & 9.5 & 33.1 \\
\hline クラッシュ & kg $\quad \mathrm{Y}$ & 91.9 & 102.2 & 154.2 & 284.0 & 89.9 & 75.6 \\
\hline $\begin{array}{l}\text { フララット } \\
\text { クラッシュ }\end{array}$ & $\mathrm{kg} / \mathrm{cm}^{2}$ & 7.7 & 4.3 & 3.1 & 7.8 & 3.4 & 1.5 \\
\hline 衝 撃 強 さ & $\mathrm{kg}-\mathrm{cm}$ & - & 82.5 & 測定不能 & 湘定不能 & 測定不能 & 49.0 \\
\hline 接 着 強 さ & $\mathrm{kg}$ & 一 & 36.9 & 11 & "l & "1 & 15.2 \\
\hline 㓮性 & ${ }_{\mathrm{kg}-\mathrm{cm}}^{\mathrm{T}}$ & 5.9 & 72.7 & 9.3 & - & 8.3 & 103.8 \\
\hline 围I & ${ }^{\mathrm{kg}-\operatorname{cin}} \mathrm{Y}$ & 14.4 & 111.8 & 20.7 & 52.2 & 16.3 & 84.9 \\
\hline & & - & 0.99 & 0.82 & - & 0.33 & 1.55 \\
\hline 最大曲け何重 & $\mathrm{Y}$ & - & 1.95 & 2.08 & - & 1.52 & 2.34 \\
\hline 箱 強 度 & 寸 法(内) & $405 \times 270 \times 2$ & $70 \mathrm{~mm} \mathrm{~A}-1$ 型 & & & & \\
\hline 重 量 & $g$ & - & 840 & 541 & - & 618 & 500 \\
\hline 圧 縮 強 度 & $\mathrm{kg}$ & - & 516 & 282 & - & 176 & 359 \\
\hline 丕量 & $\mathrm{mm}$ & - & 7.4 & 7.6 & - & 16.1 & 17.7 \\
\hline 考 & & & $\begin{array}{l}\text { ライナー } 200 \mu \\
\text { 中 } \quad \text { 芯 } 175 \mu \\
\text { ライナー } 200 \mu\end{array}$ & & & $\begin{array}{c}\text { ライナー発泡 } \\
\text { 中芯未発泡 }\end{array}$ & $\begin{array}{ll}\mathrm{K} & 220 \\
\mathrm{SCP} & 125 \\
\mathrm{~K} & 220\end{array}$ \\
\hline
\end{tabular}


ンパクトで安価であること，断面形状を種々かえるこ とができることなどの特徵があるが，生産性の低いの が欠点である。

組合せ方式は種々あり，コルゲート方式の良いとこ ろと押出し成型方式の良いところを取入れた折哀式で ある。段ボールの特改も上記両方式の中間的なもの之 なる。

\section{2 プラ段市場の現況}

第 1 表に現在プラ段を生産販売しているメーカー， 商品名，製造方法などを示す。

\section{3 各種プラ段の特性}

第 2 表に代表的なプラ段の物性を示す。

一般にプラ段の強度特性は紙段ボールに比べ，破裂 強さ，衝撃強さは比較的高い。しかし，段ボールシー トのタテ，ヨコ差が大きくかつ製造法によっては熱に よる歪が残りシートに反りが生じ易い。そのためプラ スチックといら素材からの特性と相俟って箱の圧縮強 度などの剛性面から見た強度は一般に弱い。

しかし，前述のプラスチックと無機物との複合材料 を用いた段ボールは剖性面で紙段ボールに匹敵した強 さを持っている。

\section{3. カルプ段ボール}

\section{1 組成と造製法}

カルプ段ボールは，ライオン油脂の開発した多量の 無機質充填材を樹脂の中に均一に分散させた，新しい 複合材料を原材料としている。複合材料は従来の常識 では無機物の充填量は 20～30\% が限界とされていた
製造のフローは

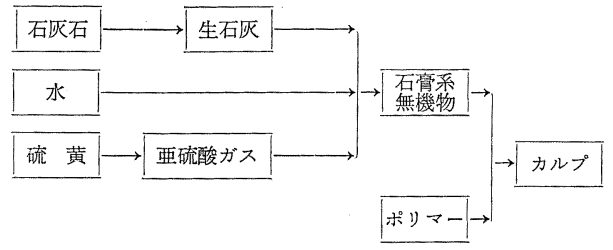

が，特殊な分子構造の高密度ポリエチレンを選択する ことにより，無機物を 60〜 70\% 充媜した材料である。 でペレットの製造はライオン油脂と出光石油化学の共 同出資による出光ライオンで行っている。

次工程の原反製造㓡よび段ボール製造・製函は，ラ イオン油脂と本州製紙の合弁による本州ライオンで受 持っている。原反製造は塩ビシートと同じようなカレ ンダー装置で行なう。段繰りは段ロールに多数小孔を あけ，フアンで吸引させて段成形を行なら独特なノー フィンガー・サクション方式を採用している。

接着剂は基材が不活性のポリエチレンであることか ら，一般のデンプンとか酢酸ビニル系の接着剤は使用 できない。種々検討したが現在はホットメルト接着剤 を使用している。

\subsection{LR-PPC 原反}

原反の一般的性質について概略を述べると第 3 表の 通りである。原反の物性については第 4 表に示す。

\section{3 カルプ段ボール}

a) 製造方式

コルゲート方式であって，原反はカレンダーで成型 し，ノーフィンガー・サクション方式のコルゲーター

第3衰 原色の一般的性質

\begin{tabular}{|c|c|c|c|c|c|c|}
\hline \multicolumn{2}{|c|}{ 項 } & \multicolumn{3}{|c|}{ 目 } & 性 & 効 \\
\hline 機 & 械 & 的 & 強 & 度 & 圧縮強さ，剛性大 & $\begin{array}{l}\text { 段ボールなど構造体の素材とし } \\
\text { て適す }\end{array}$ \\
\hline 熱 & 的 & & 特 & 徵 & $\begin{array}{l}\text { 熱膨張率小 } \\
\text { 熱伝導度大 }\end{array}$ & $\begin{array}{l}\text { 寸法安定性良 } \\
\text { 加工適性良 }\end{array}$ \\
\hline 燃 & 焼 & & 特 & 性 & $\begin{array}{l}\text { 燃焼熱 } 3,000 \mathrm{kcal} / \mathrm{kg} \text {, 有害ガ } \\
\text { ス発生無し, 自己消火性有り }\end{array}$ & 廃棄処理に便 \\
\hline 電 & 気 & & 特 & 性 & $\begin{array}{l}\text { 電気抵抗大 } \\
\text { 帯電圧小 }\end{array}$ & $\begin{array}{l}\text { 静電気の発生少なく, 帯電によ } \\
\text { る污れ小さい }\end{array}$ \\
\hline 表 & 面 & & 特 & 性 & 印刷適性良 & $\begin{array}{l}\text { オフセット，グラビア，凸版い } \\
\text { ずれも可 }\end{array}$ \\
\hline
\end{tabular}


第 4 表 LR-PPC 原区の物 性

\begin{tabular}{|c|c|c|c|c|c|c|}
\hline \multicolumn{4}{|c|}{ 項目 $\quad$ 厚さ $\mu$} & 150 & 175 & 200 \\
\hline & 坪 & \multicolumn{2}{|c|}{$\mathrm{g} / \mathrm{m}^{2}$} & 250 & 275 & 311 \\
\hline \multicolumn{2}{|l|}{ 厚 } & \multicolumn{2}{|c|}{$\mathrm{mm}$} & 156 & 175 & 201 \\
\hline \multicolumn{2}{|l|}{ 密 } & \multicolumn{2}{|c|}{$\mathrm{g} / \mathrm{cm}^{3}$} & 1.60 & 1.57 & 1.55 \\
\hline \multicolumn{2}{|c|}{ 破 裂 強 } & \multicolumn{2}{|c|}{$\mathrm{kg} / \mathrm{cm}^{2}$} & 2.7 & 3.1 & 3.5 \\
\hline $\begin{array}{l}\text { 引 } \\
\text { 張 } \\
\vdots \\
\text { 強 } \\
\text { 出 }\end{array}$ & $\begin{array}{ll}\text { 降 } & \text { 伏 } \\
\text { 破 } & \text { 断 } \\
\text { 降 } & \text { 伏 } \\
\text { 破 } & \text { 断 }\end{array}$ & \multicolumn{2}{|c|}{$\begin{array}{c}\mathrm{Tg} / \mathrm{cm}^{2} \\
\mathrm{Y}\end{array}$} & $\begin{array}{l}190 \\
400 \\
121 \\
101\end{array}$ & $\begin{array}{l}217 \\
423 \\
116 \\
102\end{array}$ & $\begin{array}{l}214 \\
410 \\
106 \\
112\end{array}$ \\
\hline $\begin{array}{l}\text { 伸 } \\
\text { び }\end{array}$ & $\begin{array}{ll}\text { 降 } & \text { 伏 } \\
\text { 破 } & \text { 断 } \\
\text { 降 } & \text { 伏 } \\
\text { 破 } & \text { 断 }\end{array}$ & \multicolumn{2}{|c|}{$\begin{array}{ll} & \mathrm{T} \\
\% & \\
& \mathrm{Y}\end{array}$} & $\begin{array}{r}1.4 \\
26.2 \\
0.8 \\
50.0\end{array}$ & $\begin{array}{r}1.6 \\
35.0 \\
0.9 \\
73.6\end{array}$ & $\begin{array}{r}2.0 \\
47.3 \\
1.1 \\
90.3\end{array}$ \\
\hline \multicolumn{2}{|c|}{ 引裂き強さ } & & $\begin{array}{l}\mathrm{T} \\
\mathrm{Y}\end{array}$ & $\begin{array}{l}300 \\
100\end{array}$ & $\begin{array}{l}380 \\
125\end{array}$ & $\begin{array}{l}430 \\
150\end{array}$ \\
\hline \multicolumn{2}{|c|}{ 耐 折 強 さ } & & $\begin{array}{l}\mathrm{T} \\
\mathrm{Y}\end{array}$ & $\begin{array}{l}1,000> \\
1,000>\end{array}$ & $\begin{array}{l}1,000> \\
1,000>\end{array}$ & $\begin{array}{l}1.000> \\
1,000>\end{array}$ \\
\hline \multicolumn{2}{|c|}{$\begin{array}{c}\text { ヤング率 } \\
\text { (曲げ) }\end{array}$} & \multicolumn{2}{|c|}{$\begin{array}{l}\times 10^{7} \mathrm{~T} \\
\mathrm{~g} / \mathrm{cm}^{2} \mathrm{Y}\end{array}$} & $\begin{array}{l}5.90 \\
6.40\end{array}$ & $\begin{array}{l}5.80 \\
6.20\end{array}$ & $\begin{array}{l}5.60 \\
5.80\end{array}$ \\
\hline \multicolumn{2}{|c|}{ 圧 縮 強 さ } & \multicolumn{2}{|l|}{$\mathrm{kg}$} & $\begin{array}{l}23.4 \\
24.3\end{array}$ & $\begin{array}{l}32.0 \\
33.0\end{array}$ & $\begin{array}{l}44.1 \\
45.7\end{array}$ \\
\hline
\end{tabular}

\section{で貼合する。}

\section{b) 生産能力}

$$
\begin{array}{ll}
\text { カレンダー } & 100 \sim 150 \mathrm{~m} / \text { 分 } \\
\text { コルゲーター } & 100 \sim 150 \mathrm{~m} / \text { 分 }
\end{array}
$$

他のプラ段に比べ生産性が高い。

c) 接着方法

ホットメルト接着剂学使用する。

d）生産対応性

ライナー，中芯を他のいろいろな素材と組合せるこ とにより，需要に適した段ボールの製造が可能である。 例党ば中芯に LR-PPC 原反を使用して，ライナーに 従来の板紙を使用することも可能である。（後述コン ビネーション段ボール参照)

e) 段ボールの物性

第 5 表にカルプ段ボールのシートおよび箱強度を示 于。

$$
\text { カルプ段ボールの特徴に }
$$

1. 他のプラ段と比較して剛性が大きく, 紙段ボール と匹敵し得る。

2. 貼合工程では熱を使用しないのでシートに反りの 発生がない。
3. 完全耐水性である。

4. 美粧性がある。

5. 紙その他の素材との組合せが可能。

6. 他のプラ段と比較して廃衰処理が簡単である。

7. 加工適性が良好。

8. B段特よびC段を採用している。特にCフルート の特徵を発揮している。

この反面次のような問題点がある。

1. 動的強度が比較的弱い。

2. 温度適用範囲が比較的狭い。

$$
-15^{\circ} \mathrm{C} \text { 以下では脆化する。 }
$$$$
+50^{\circ} \mathrm{C} \text { 以上では軟化する。 }
$$

即与 $-15^{\circ} \mathrm{C}<$ 使用温度 $<+50^{\circ} \mathrm{C}$

3. 比重 1.6 (原反) で比較的重い。

カルプ段ボールは以上のような長所欠点をもつが。 これ等の特性を十分把握して需要を開発すべきであ ろら。

今までの用途としては，製函加工性が優れているが， 紙段ボールに比して動的強度が弱い点を考慮して，内 容品重量 $10 \mathrm{~kg}$ 以下の組立型式の箱に多く使用されて いる。 
第 5 表 カルプ段ボールの物性

\begin{tabular}{|c|c|c|c|c|c|c|c|}
\hline$\sqrt{3}$ & 種 類 & 力 & ルプ & ボー & ル & \multicolumn{2}{|c|}{ 紙段ボール } \\
\hline \multirow{3}{*}{ 項 目 } & \multirow{3}{*}{ 反 ${ }_{\text {構 }}$} & $175 \mu$ & $200 \mu$ & $150 \mu$ & $200 \mu$ & K $\quad 220$ & $\mathrm{~K} \quad 280$ \\
\hline & & $150 \prime \prime$ & $175 \prime \prime$ & $150 \prime \prime$ & $175 \prime \prime$ & SCP 125 & SCP 125 \\
\hline & & $175 \prime \prime$ & $200 \prime \prime$ & $150 \prime \prime$ & $200 \prime \prime$ & 220 & K $\quad 280$ \\
\hline 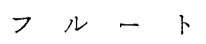 & - & $\mathrm{C}$ & $\mathrm{C}$ & $\mathrm{B}$ & B & & $\mathrm{A}$ \\
\hline 米 坪 量 & $\mathrm{g} / \mathrm{m}^{2}$ & 996 & 1,080 & 900 & 1,110 & 650 & 770 \\
\hline 厚 & $\mathrm{mm}$ & 4.2 & 4.3 & 2.9 & 3.1 & 5.1 & 5.3 \\
\hline 破 裂 強 さ & $\mathrm{kg} / \mathrm{cm}^{2}$ & 8.0 & 10.5 & 6.3 & 10.0 & 16.4 & 21.5 \\
\hline $\begin{array}{llll}\text { コ } & & \text { ム } \\
\text { ク } & \text { シ } & \text { ュ }\end{array}$ & $\begin{array}{ll}k g & \mathrm{~T} \\
\mathrm{Y}\end{array}$ & $\begin{array}{l}18.9 \\
83.4\end{array}$ & $\begin{array}{r}21.5 \\
102.2\end{array}$ & $\begin{array}{l}19.3 \\
78.7\end{array}$ & $\begin{array}{r}37.6 \\
111.5\end{array}$ & $\begin{array}{l}33.1 \\
75.6\end{array}$ & $\begin{array}{l}51.8 \\
90.5\end{array}$ \\
\hline 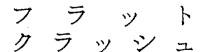 & $\mathrm{kg} / \mathrm{cm}^{2}$ & 3.3 & 4.3 & 6.1 & 5.8 & 1.5 & 1.5 \\
\hline 衝 撉 強 さ & $\mathrm{kg}-\mathrm{cm}$ & 64.0 & 82.5 & 40.4 & 78.6 & 49.0 & 60.7 \\
\hline 接 着 強 さ & $\mathrm{kg}$ & 58.4 & 36.9 & - & 36.7 & 15.2 & 18.1 \\
\hline 剛! & $k g-\mathrm{cm}_{\mathrm{Y}}^{\mathrm{T}}$ & $\begin{array}{l}58.4 \\
78.8\end{array}$ & $\begin{array}{r}72.7 \\
111.8\end{array}$ & $\begin{array}{l}30.0 \\
43.9\end{array}$ & $\begin{array}{l}39.2 \\
59.3\end{array}$ & $\begin{array}{r}103.8 \\
84.9\end{array}$ & $\begin{array}{l}107.5 \\
111.6\end{array}$ \\
\hline 最大曲林荷重 & $\begin{array}{ll}\mathrm{kg} & \mathrm{T} \\
\mathrm{Y}\end{array}$ & $\begin{array}{l}0.76 \\
1.17\end{array}$ & $\begin{array}{l}0.99 \\
1.95\end{array}$ & $\begin{array}{l}0.36 \\
0.87\end{array}$ & $\begin{array}{l}0.81 \\
1.30\end{array}$ & $\begin{array}{l}1.55 \\
2.34\end{array}$ & $\begin{array}{l}1.94 \\
2.49\end{array}$ \\
\hline \multicolumn{8}{|l|}{ 箱強度 } \\
\hline 寸 法（内） & $\mathrm{mm}$ & \multicolumn{4}{|c|}{$405 \times 270 \times 270$} & \multicolumn{2}{|c|}{$405 \times 270 \times 270$} \\
\hline 重 & $g$ & 748 & 840 & 696 & 754 & 500 & 600 \\
\hline 压縮 強 度 & $\mathrm{kg}$ & 445 & 516 & 278 & 365 & 359 & 401 \\
\hline 量 & $\mathrm{mm}$ & 6.4 & 7.4 & 3.0 & 4.0 & 17.7 & 15.6 \\
\hline
\end{tabular}

第 6 表 コンビ段ボールの物性

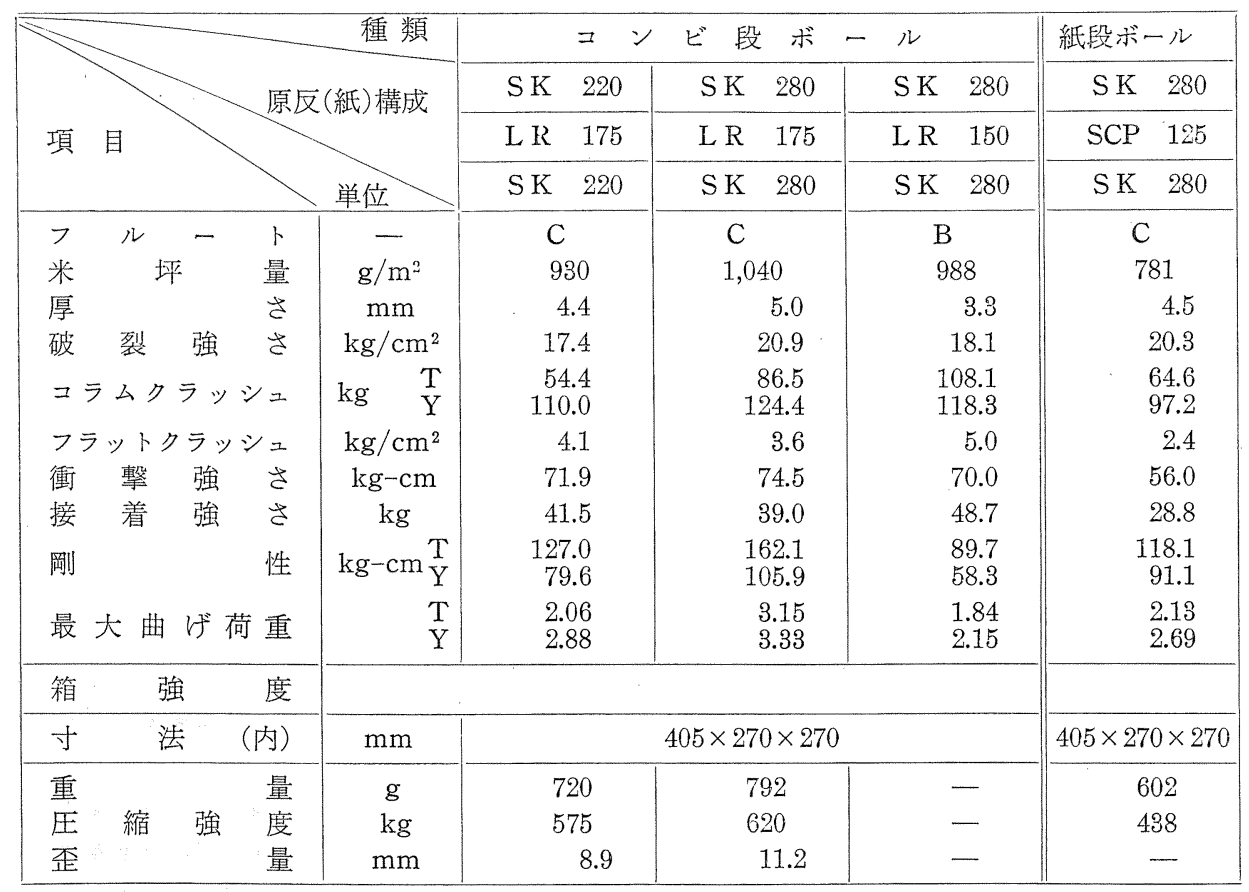


䂆水強度残留率

第7表 コンビネーション段ボールの耐水性

\begin{tabular}{|c|c|c|c|c|c|c|c|}
\hline \multicolumn{4}{|c|}{ 試験条件 種 類 } & $\begin{array}{c}\text { コンビ段ボール } \\
\mathrm{A}\end{array}$ & $\begin{array}{c}\text { コンビ段ボール } \\
\mathrm{B}\end{array}$ & 含浸段ボール & $\begin{array}{c}\text { 一般段ボール } \\
\text { (紙) }\end{array}$ \\
\hline 高 & 温 & 高 & 湿 & 54.3 & 65.3 & 50.3 & 50.0 \\
\hline 散 & & & 水 & 53.2 & 72.5 & 62.8 & 22.3 \\
\hline 浸 & & & 水 & 37.0 & 50.4 & 16.7 & 0 \\
\hline
\end{tabular}

注）簿, 寸法 (内) $405 \times 270 \times 270 \mathrm{~mm}, \mathrm{~A}-1$ 型テープ I貼り

高温高湿: $40^{\circ} \mathrm{C}, 90 \% \mathrm{RH} 5 \mathrm{hr}$ 放置

散 水: 水量 $110 \mathrm{~mm} / \mathrm{hr}, 3 \mathrm{hr}$ 散水

浸 水: $20^{\circ} \mathrm{C}$ の水飞 $150 \mathrm{~mm}$ 浸水, $1 \mathrm{hr}$ 放置

コンビ段ボール A：ライナー耐水ライナー

中芯 LR-PPC 原反使用

" $\mathrm{B}:$ コンビ段ボールAKカーテンコーターでワックス处理を施す。 含浸段ボール：約 $50 \%$ の含浸率

また使用分野として

トロ箱など水産物

青果物，贈答品関係，コールドチェーン用包

装などに適している。

反面，大型のト口箱や冷凍箱 $\left(-20^{\circ} \mathrm{C}\right.$ 以下 $)$ の包 装には，原反改良を進める中で今後に期待したい分野 である。

\section{4. コンビネーション段ボール}

プラ段は前述したように，紙段ボールにない特徴を 持つと同時にまた欠点もある。

そこで紙とプラスチック，特に紙と LR-PPC 原反 との組合せによりこれ等の欠点を補い，更に特徵を伸 ばそうといら考えのもとにコンビネーション段ボール

（以後簡略のためにコンビ段ボールと呼ぶ）の開発を 行った。

原紙（原区）の構成としてはライナーに紙，中芯を LR-PPC 原反，または中芯に紙，ライナーにLR-PPC 原反などの組合せが考兵られる。

第6表は中芯に LR-PPC 原反を用いた段ボールの 物性を示す。

コンビ段ボールは剛性が大きくなり，箱の圧縮強度， 例えば S K 280/L R 175 $\mu /$ S K 280 の組合せの場合は
$\mathrm{K} 220$ の複両面段ボールに匹敵する強度を持つ。

また，中芯に LR-PPC 原反を使用したコンビ段ボ ールは，接着片にホットメルトを使用することにより 耐水性にすぐれ，含浸段ボールと比較してもすぐれて 牧り，特に表面にカーテン・コーターで更に耐水処理 を行えば一層その効果が発揮できる。（第 7 表）

コンビ段ボールの用途としては，その強度面から見 て複両面の代替，また強度と耐水性にすぐれている点 からトロ箱や冷凍用箱の分野への適用が期待できる。

\section{5. ま め}

ここ数年，各種のプラスチック段ボールが開発され 市場にでてきたが，夫々一長一短がある。しかし，一 般的に言えることは，その耐水性と美粧性は従来の紙 段ボールになかった大きな特徴であろら。その反面, 剛性拉よび価格についてはまだ紙段ボールに一歩譲る のが現状であろら。

今後はこれ等剛性面の改善, 包装公害の問題, 更に

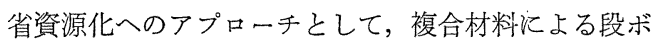
一ル，また，これ等材料と紙との組合せによりその特 徵を生かしたコンビネーション段ボールの伸長が期待 できる。

\section{8th Cellulose Conference}

共催; the Wood Chemistry Committee of TAPPI and the Cellulose Research Institute of the State University of New York's College of Environmental Science and Forestry

主題; "Wood Chemicals-a Future Challenge" 場所; Syracuse, New York.

期間；1975 年 5 月 20-22 日
論文提出先；Dr. T. E. Timell，

Department of Chemistry, SUNY College of Environmental Science and Forestry, Syracuse, N. Y. 13210

照会先; Technical Association of the Pulp \& Paper Industry One Dunwoody Park, Atlanta, Georgia 30341 